\title{
Vigor and alpha-amylase activity in common bean seeds under salt stress conditions
}

\section{Vigor e atividade de alfa-amilase sementes de feijão em condições de estresse salino}

\author{
Matheus Santin Padilha ${ }^{1}$; Cileide Maria Medeiros Coelho2*; Natalia Carolina \\ Moraes Ehrhardt-Brocardo ${ }^{3}$
}

\section{Highlights}

Salt stress negatively affects the mobilization of seed reserves.

Alpha-amylase activity decreases in the presence of salt stress.

Seeds with greater vigor have greater alpha-amylase activity in absence of stress.

\begin{abstract}
Seeds with high vigor have greater capacity for hydrolysis and mobilization of stored reserves, which results in the formation of vigorous seedlings, and this behavior is observed under abiotic stress conditions. This study proposes to investigate the relationship of the enzyme alpha-amylase in lots of common-bean seeds with contrasting vigor, when subjected to the absence and presence of salt stress, aiming to identify the relationship of this enzyme with the vigor of the seed lot under these conditions. Seven common-bean cultivars were used. Physiological quality was determined by germination, vigor index and seedling length. The mobilization of reserves was evaluated under absence and presence of salt stress simulated with a $\mathrm{NaCl}$ solution with a concentration of $50 \mathrm{mmol} \mathrm{L}^{-1}$. The analyzed variables regarding reserve mobilization were reserve reduction, reserve reduction rate, seedling dry weight, reserve mobilization rate, starch, starch reduction rate and alpha-amylase activity. Results showed that the stress condition negatively affected all the evaluated variables; however, the cultivars classified as having greater vigor showed better physiological performance under stress. Salt stress in common-bean seeds affects seedling performance and reduces alpha-amylase activity during germination, and high-vigor seed lots exhibited higher enzyme activity in the no-stress condition.
\end{abstract}

Key words: Phaseolus vulgaris L. Germination. Seedling vigor.

1 M.e in Plant Production, Universidade do Estado de Santa Catarina, Centro de Ciências Agroveterinárias, UDESC/ CAV, Lages, SC, Brazil. E-mail: matheus_santin@hotmail.com

2 Profa Dra, Department of Agronomy, UDESC/CAV, Lages, SC, Brazil. E-mail: cileide.souza@udesc.br

${ }^{3}$ Dra in Plant Production, Centro de Educação Santa Teresinha, CEST/Sagrada, Curitibanos, SC, Brazil. E-mail: biosapos@gmail.com

* Author for correspondence

Received: May 09, 2021 - Approved: Sept. 29, 2021 


\section{Resumo}

As sementes com alto vigor possuem maior capacidade de hidrólise e mobilização das reservas armazenadas resultando na formação de plântulas vigorosas, sendo esse comportamento observado em condições de estresse abiótico. O objetivo deste trabalho foi avaliar a relação da enzima alfa-amilase em lotes de sementes de feijão com contraste no vigor quando submetidos a condições de ausência e presença de estresse salino, buscando identificar a relação desta enzima com o vigor do lote de sementes nessas condições. Sete cultivares de feijão foram utilizadas. A qualidade fisiológica foi determinada pela germinação, índice de vigor e comprimento de plântulas. A mobilização de reservas foi avaliada em condições com ausência e presença de estresse salino simulado com solução de $\mathrm{NaCl}$ com concentração de $50 \mathrm{mmol} \mathrm{L}^{-1}$. As variáveis analisadas referentes a mobilização de reservas foram a redução das reservas, taxa de redução das reservas, massa seca de plântulas, taxa de mobilização de reservas, amido, taxa de redução de amido e atividade da alfa-amilase. Os resultados demonstraram que a condição de estresse afetou negativamente todas as variáveis avaliadas, contudo, as cultivares classificadas como de maior vigor apresentaram melhor desempenho fisiológico sob o estresse. $O$ estresse salino em sementes de feijão afeta o desempenho de plântulas e reduz a atividade da alfa-amilase durante a germinação e, os lotes de sementes com alto vigor apresentaram maior atividade da enzima em condições de ausência de estresse.

Palavras-chave: Phaseolus vulgaris L. Germinação. Vigor de plântulas.

\section{Introduction}

The common bean (Phaseolus vulgaris L.) is produced and consumed mainly in developing countries in Latin America, Africa and Asia. It is one of the most important legumes in the world, given its use in human nutrition as a source of starch, protein, fiber and minerals (Mukankusi et al., 2017; J. Chen et al., 2016).

This crop is typically grown in arid and semi-arid regions, which are susceptible to natural soil salinization (Dutta, Neelapu, Wani, \& Challa, 2018). Saline soils can compromise agricultural production due to negative effects on germination, affecting plant stand, root and shoot lengths and biomass accumulation (Liang, Ma, Wan, \& Liu, 2018). One of the strategies to foster the initial establishment of seedlings under these conditions is the use of seeds of high physiological quality. This is because vigor is the set of attributes that determines the potential for rapid and uniform emergence of a seedling in a wide variety of conditions (International Seed Testing Association [ISTA], 2014), which has an impact on crop yield (Mondo, Nascente, \& Cardoso, 2016; Caverzan et al., 2018).

The establishment of seedlings in the field is determined by the heterotrophic growth process (Gommers \& Monte, 2018), which depends on the hydrolysis and mobilization of components stored in the seed reserve tissue to the embryonic axis (Bewley, Bradford, Hilhorst, \& Nonogaki, 2013). Efficiency in hydrolysis and mobilization of reserves favors the formation of vigorous seedlings, one of the aspects associated with seed vigor (J. Cheng et al., 2015; Andrade, Coelho, \& Padilha, 2019). In general, this process can be influenced by adverse conditions imposed by the environment, such as water, salt and 
thermal stress, heavy metals, among others (Kalai, Bouthour, Manai, Bettaieb-Ben Kaab, \& Gouia, 2016; El-Mowafy \& Kishk, 2017).

Legume seeds contain a large amount of carbohydrates in their composition, including starch (Tayade, Kulkarni, Jo, Song, \& Lee, 2019). The evaluation of starch hydrolysis and mobilization in species of the family Fabaceae is little explored in the literature, when compared with species of the family Poaceae (Bewley et al., 2013). Starch is a readily available source of energy and metabolites for seedling growth, and alpha-amylase is the main enzyme responsible for its hydrolysis, which favors seedling establishment (Yu, Lo, \& Ho, 2015).

Several studies sought to associate the activity of the alpha-amylase enzyme with the initial vigor of the seed lot. In maize seeds subjected to germination without abiotic stress, high-vigor seeds showed greater alphaamylase enzyme activity during the processes of germination and seedling formation (Oliveira et al., 2013), and the same was observed in rice seeds (X. Cheng et al., 2013). However, in soybean seeds, the relationship between greater seed vigor and the activity of this enzyme was not observed (Henning et al., 2010). In wheat, L. T. Chen et al. (2017) demonstrated that alpha-amylase activity and seed vigor were positively correlated in the condition of germination in the absence of stress, but no positive association occurred when seeds were subjected to water stress.

Associating the activity of the alpha-amylase enzyme with seed vigor and determining to which extent vigor can provide better physiological performance during an abiotic stress situation with the involvement of this enzyme are very relevant for understanding the physiological quality of common-bean seeds, given the lack of research on this topic. Thus, the hypothesis tested in the present study is that commonbean seeds with greater vigor exhibit higher alpha-amylase activity in the absence and presence of salt stress, with greater starch hydrolysis favoring the formation of seedlings with better physiological performance under these conditions. Based on the presented hypotheses, the objective of this study was to investigate the behavior of the alpha-amylase enzyme in lots of common-bean seeds with contrasting vigor in ideal conditions and under salt stress, aiming to identify the relationship of this enzyme with the initial vigor of the common-bean seed lot.

\section{Material and Methods}

Seed lots of cultivars BAF07, BAF13, BAF23, BAF42, BAF55, BAF81 and BAF112 were used. The seeds were produced in the municipality of Lages - SC, Brazil, in the experimental area of the Center for Agricultural Sciences at Santa Catarina State University (UDESC-CAV), in the 2018/2019 crop. After harvesting, they were homogenized and 1000 $\mathrm{g}$ of seeds were separated to determine the average sample, and the working sample for further analysis was obtained later (Ministério da Agricultura, Pecuária e Abastecimento [MAPA], 2009). The seeds were stored in a dry chamber $\left(10 \pm 2{ }^{\circ} \mathrm{C}\right.$ and $50 \pm 5 \%$ relative humidity) until analysis.

The seed lots were characterized in terms of physiological quality based on germination test, vigor index and seedling length, which were evaluated in the absence (Control) and presence of salt stress ( $\mathrm{NaCl}$ ). 
Salt stress was induced using a solution with $50 \mathrm{mmol} \mathrm{L}^{-1}$ of sodium chloride ( $\mathrm{NaCl}$ ) with an electrical conductivity of $5.07 \mathrm{dS} \mathrm{m}^{-1}$ to wet the paper (rate of $2.5 \mathrm{~mL} \mathrm{~g}^{-1}$ of dry paper).

The germination test was conducted with three replicates in a Mangelsdorf germinator at a temperature of $23 \pm 2^{\circ} \mathrm{C}$ using a photoperiod of $12 \mathrm{~h}: 12 \mathrm{~h}$ light:dark. Seeding was performed on Germitest ${ }^{\circledR}$ paper substrate in the form of a roller moistened with distilled water (Control) or saline solution $(\mathrm{NaCl})$ at the rate of $2.5 \mathrm{~mL} \mathrm{~g}^{-1}$ of dry paper. The number of normal seedlings was counted as described by MAPA (2009), at five and nine days after the start of the test.

To determine vigor index, three replicates of 20 seeds were placed on the paper (Krzyzanowski, França, Gomes, \& Nakagawa, 2020). The rolls were moistened at the rate of $2.5 \mathrm{~mL} \mathrm{g-1}$ of dry paper with distilled water (Control) or saline solution $(\mathrm{NaCl})$, as described above, and kept in a Mangelsdorf germinator at $23 \pm 2{ }^{\circ} \mathrm{C}$ for three days. After this time, the seedlings considered normal had the hypocotyl, root and total lengths measured with a digital caliper. Vigor index (VI) was calculated according to the formula proposed by Sako, McDonald, Fujimura, Evans and Bennet (2001), using R software (R Core Team $[R], 2020)$ and the SeedCalc package (Silva, Medeiros, \& Oliveira, 2019), as shown below:

$$
\begin{gathered}
\text { Vigor Index }(V I)=\left(w G \times\left(w_{h} \times I_{h}+w_{r} \times I_{r}\right)\right)+ \\
\left(w U \times\left(1000-\left(w_{s h} \times s_{h}+w_{s r} \times s_{r}+s_{\text {total }}+\right.\right.\right. \\
\left.\left.w_{s r / h} \times s_{r / h}\right)-w d \times \text { numdead }\right)
\end{gathered}
$$

where $I_{h}$ and $I_{r}$ are the average hypocotyl and root lengths of the samples, respectively; $s_{h^{\prime}}$ $\mathrm{s}_{\mathrm{r}} \mathrm{s}_{\text {total }}$ and $\mathrm{s}_{\mathrm{r} / \mathrm{h}}$ are the standard deviations of hypocotyl length, root length, total length and root/hypocotyl ratio, respectively; w represents the proportion for the growth (G) and uniformity (U) parameters; wd stands for penalty for the number of dead seeds; and numdead is the number of dead seeds.

Mobilization of reserves was evaluated five days after sowing, as described above. This variable was evaluated in the absence and presence of salt stress (Control and $\mathrm{NaCl}$ ) using three replicates of 20 seeds. On the fifth day after test was set up, the seedlings were measured with a digital caliper to determine the total seedling length (TL). After separating the cotyledons and seedlings, the material was dried at a temperature of $80^{\circ} \mathrm{C}$ for $24 \mathrm{~h}$ to determine the remaining dry weight in the cotyledons (RDWC) and seedling dry weight (S.DW) (Krzyzanowski et al., 2020). Seed dry weight $\left(S_{D} D W\right)$ was determined after removing the seed coat from four replicates of 20 seeds and subsequently oven-drying at 105 ${ }^{\circ} \mathrm{C}$ for $24 \mathrm{~h}$. The RDWC was corrected for the rate of remaining dry weight in cotyledons by the equation $\left[R D W C=\left(\right.\right.$ RDWC $(\mathrm{mg}) / S_{D} D W$ $\left.(\mathrm{mg}))^{*} 100\right]$. Seed reserve reduction $\left(S_{D} R R\right)$ $\left[S_{D} R R=S_{D} D W(m g)-R_{D} W C(m g)\right]$, seed reserve reduction rate $\left(S_{D} R R R\right)\left[S_{D} R R R=\left(S_{D} R R(m g)\right) /\right.$ $S_{D}$ DW (mg))*100] (Soltani, Gholipoor, \& Zeinali, 2006) and reserve mobilization rate (RMR) [RMR $=\left(S_{L}\right.$ DW $\left.(\mathrm{mg}) / S_{D} D W(m g){ }^{*} 100\right]$ (Andrade et al., 2019) were also determined.

Starch extraction and quantification were performed before the seeds were subjected to germination (initial) and at the end of the test (five days after sowing). These determinations were conducted as proposed by McCready, Guggolz, Silveira and Owens (1950), with modifications. For extraction, 125 $\mathrm{mg}$ of dry flour ground in a mortar were placed in a centrifuge tube. The soluble sugars were 
extracted in a double-step process with $80 \%$ alcohol, whereas the starch was extracted from the residue in a double-step process with $52 \%$ perchloric acid. Quantification was achieved using $1 \mathrm{~mL}$ of the diluted extract and $3 \mathrm{~mL}$ of anthrone, followed by vortexing for $3 \mathrm{~s}$. The test tubes were kept in a water bath at $95^{\circ} \mathrm{C}$ for $450 \mathrm{~s}$, after which time reading was performed in a spectrophotometer at an absorbance of $630 \mathrm{~nm}$. The standard curve was determined using the solution with glucose concentrations of $10,20,30,40,50$ $\mu \mathrm{g} \mathrm{mL}^{-1}$. Results were expressed in $\mathrm{mg} \mathrm{seed}^{-1}$.

Starch reduction rate $\left(S_{T} R R\right)$ was determined from the results of initial starch (IS) and starch remaining after five days (FS), given by the equation below:

Starch reduction rate $\left(\mathrm{S}_{\mathrm{T}} \mathrm{RR}\right)=$

$\left(\frac{\left.\text { IS }\left(\mathrm{mg} \mathrm{seed}^{-1}\right)-\mathrm{FS}^{(\mathrm{mg} \mathrm{seed}}{ }^{-1}\right)}{\text { IS }\left(\mathrm{mg} \mathrm{seed}^{-1}\right)}\right) \times 100$

Alpha-amylase activity (EC 3.2.1.2) was determined by the 3,5-dinitrosalicylic acid (DNS) method (Miller, 1959). Using the procedure described by Sun and Henson (1991) with modifications. To obtain the enzyme extract, $500 \mathrm{mg}$ of previously ground fresh flour was mixed with liquid nitrogen and

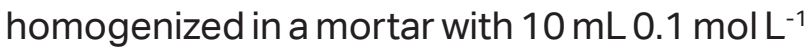
TRIS-HCL buffer ( $\mathrm{pH} 7.2$ ) containing $0.1 \mathrm{~mol} \mathrm{~L}^{-1}$ $\mathrm{NaCl}$ and $10 \mathrm{mmol} \mathrm{L}^{-1} \mathrm{CaCl} 2$ and centrifuged for $10 \mathrm{~min}$ at a temperature of $6^{\circ} \mathrm{C}$. The extract was incubated in a water bath for $15 \mathrm{~min}$ at 70 ${ }^{\circ} \mathrm{C}$. Quantification was achieved using $500 \mu \mathrm{L}$ enzyme extract, $500 \mu \mathrm{L}$ sodium acetate buffer solution (100 mmol L-1) containing $5 \mathrm{mmol} \mathrm{L}^{-1}$ calcium chloride ( $\mathrm{pH} 5.0$ ) and $500 \mu \mathrm{L}$ starch solution containing $2.5 \%(\mathrm{w} / \mathrm{v})$. The samples remained in a water bath for $15 \mathrm{~min}$ at $40^{\circ} \mathrm{C}$. The reaction was stopped with the addition of $1000 \mu \mathrm{L}$ of DNS solution and the samples were subsequently kept in a water bath for 6 min at $95^{\circ} \mathrm{C}$. Before reading, $7.5 \mathrm{~mL}$ distilled water were added. Reading was performed in a spectrophotometer at an absorbance of 540 $\mathrm{nm}$ and results were expressed in units per milliliter $\left(\mathrm{U} \mathrm{mL}^{-1}\right)$. One enzyme unit was defined as the amount of enzyme to produce $1 \mu \mathrm{mol}$ of glucose per minute under the evaluated conditions.

The experiment was laid out in a $7 \times 2$ factorial arrangement (seven cultivars and two germination conditions) with three replicates. Statistical analyses were carried out using $R$ software (R, 2020). Results were subjected to analysis of variance ( $F$ test), and the comparison between means and interactions was done using the Scott-Knott test at 5\% probability. Principal component analysis (PCA) was observed for each germination condition without stress (Control) and with salt stress $(\mathrm{NaCl})$, separately to identify associations between parameters in each condition. As a complement to identify the association between vigor and alpha-amylase activity, Pearson's correlation analysis was conducted performed between these variables and significance was identified by the $t$ test.

\section{Results and Discussion}

The summary of analysis of variance indicates a significant effect ( $p \leq 0.05$ ) of the genotypes used and the imposed stress. There was an interaction effect between the factors for the variables of vigor index (VI), total seedling length (TL), seedling dry weight $(S, D W)$, seedling reserve mobilization rate (RMR) and alpha-amylase activity $(\alpha)$. For the other variables, there was no interaction effect (Table 1). 
Table 1

Summary of analysis of variance informing the significance $(p \leq 0.05)$ obtained for the analyzed variables

\begin{tabular}{|c|c|c|c|c|c|c|c|c|c|c|c|c|}
\hline SV & DF & $\mathrm{G}$ & VI & $\mathrm{TL}$ & $\mathrm{S}_{\mathrm{L}} \mathrm{DW}$ & $\mathrm{R}_{\mathrm{D}} \mathrm{WC}$ & $S_{D} R R$ & $S_{D} R R R$ & RMR & $\mathrm{FS}$ & $S_{T} R R$ & $\alpha$ \\
\hline $\mathrm{F} 1$ & 6 & ** & * & * & * & * & * & * & * & * & * & * \\
\hline F2 & 1 & * & * & * & * & * & * & * & * & * & * & * \\
\hline $\mathrm{F} 1 \times \mathrm{F} 2$ & 6 & ns & * & ** & * & ns & ns & ns & * & ns & ns & * \\
\hline Error & 28 & & & & & & & & & & & \\
\hline Total & 41 & & & & & & & & & & & \\
\hline CV & - & 3.29 & 4.56 & 4.96 & 4.76 & 3.89 & 7.53 & 6.88 & 4.07 & 12.82 & 14.00 & 11.84 \\
\hline
\end{tabular}

SV: Source of variation; F1: Cultivar; F2: Stress; DF: Degrees of freedom; CV: coefficient of variation. ${ }^{*}{ }^{* *}$, ns: Significant at $1 \%$ and $5 \%$ probability and not significant, respectively. G: Germination; VI: Vigor index; TL: Total length; SLDW: Seedling dry weight; RDWC: Remaining dry weight in cotyledons; SDRR: Seed reserve reduction; SDRRR: Seed reserve reduction rate; RMR: Reserve mobilization rate; FS: Final starch; STRR: starch reduction rate; and $\alpha$ : Alpha-amylase activity.

Considering the overall mean of the variables for the characterization of physiological quality, the isolated effect of the germination condition was negative under the imposed salt stress ( $p \leq 0.05$ ). When the seeds were subjected to tests in the presence of salt stress, performance declined. Between the variables of germination, vigor index and total length, the decreasing effect was more accentuated in vigor index and total length (Table 2).

Germination percentage ranged from $85 \%$ to $94 \%$ between the cultivars in the nonstressed condition and from $85 \%$ to $91 \%$ when the seeds were subjected to salt stress. Cultivars BAF07 and BAF112 showed lower germination in the control condition, whereas no significant difference between the cultivars occurred under stress (Table 2). This smaller effect on germination percentage allows a more detailed study of seed vigor, since all cultivars have the capacity to germinate under the imposed conditions. Thus, the vigor index and the total length of the seedlings were determined to identify vigor groups among te cultivars used.
The vigor index demonstrates the difference between the lots of cultivars used. Under both conditions, cultivar BAF55 showed the greatest vigor. The lowest indices were observed for cultivars BAF07, BAF23 and BAF42 in the control condition. However, in the presence of stress, cultivar BAF42 showed greater vigor than BAF07 and BAF23 (Table 2). The differences in vigor were confirmed by the results of seedling length, for which cultivars BAF13, BAF42, BAF55, BAF81 and BAF112 showed higher values than BAF07 and BAF23, in both germination conditions. Vigor index and seedling length are efficient tests for the segregation of seed vigor of several species, as they assess the speed, uniformity and performance of seedlings in the lot (Marcos, 2015; Rocha, Silva, \& Cícero, 2015; Silva et al., 2019). In this way, two distinct vigor groups were defined: the higher-vigor group (BAF13, BAF42, BAF55, BAF81 and BAF112) and the lower-vigor group (BAF07 and BAF23). 
Table 2

Germination, vigor index and total seedling length (TL) of lots of seeds of common-bean cultivars evaluated in the absence (Control) and presence of salt stress with $50 \mathrm{mmol} \mathrm{L}^{-1}(\mathrm{NaCl})$

\begin{tabular}{ccccccc} 
& \multicolumn{2}{c}{ Germination (\%) } & \multicolumn{2}{c}{ Vigor index } & \multicolumn{2}{c}{ TL (mm) } \\
\cline { 2 - 7 } Cultivar & Control & $\mathrm{NaCl}$ & Control & $\mathrm{NaCl}$ & Control & $\mathrm{NaCl}$ \\
BAF07 & $85 \mathrm{~b}^{1}$ & $85 \mathrm{a}$ & $601 \mathrm{Ae}$ & $444 \mathrm{Bc}$ & $174.63 \mathrm{Ad}$ & $85.17 \mathrm{Bd}$ \\
BAF13 & $91 \mathrm{a}$ & $89 \mathrm{a}$ & $810 \mathrm{Ab}$ & $517 \mathrm{Bb}$ & $231.21 \mathrm{Ab}$ & $126.19 \mathrm{Bb}$ \\
BAF23 & $89 \mathrm{a}$ & $87 \mathrm{a}$ & $702 \mathrm{Ad}$ & $448 \mathrm{Bc}$ & $205.57 \mathrm{Ac}$ & $107.07 \mathrm{Bc}$ \\
BAF42 & $88 \mathrm{a}$ & $85 \mathrm{a}$ & $728 \mathrm{Ad}$ & $515 \mathrm{Bb}$ & $218.09 \mathrm{Ab}$ & $133.23 \mathrm{Bb}$ \\
BAF55 & $94 \mathrm{a}$ & $91 \mathrm{a}$ & $854 \mathrm{Aa}$ & $582 \mathrm{Ba}$ & $257.21 \mathrm{Aa}$ & $152.97 \mathrm{Ba}$ \\
BAF81 & $90 \mathrm{a}$ & $88 \mathrm{a}$ & $774 \mathrm{Ac}$ & $503 \mathrm{Bb}$ & $218.08 \mathrm{Ab}$ & $138.23 \mathrm{Bb}$ \\
BAF112 & $85 \mathrm{~b}$ & $87 \mathrm{a}$ & $810 \mathrm{Ab}$ & $500 \mathrm{Bb}$ & $227.14 \mathrm{Ab}$ & $144.65 \mathrm{Ba}$ \\
Overall mean & $90 \mathrm{~A}$ & $87 \mathrm{~B}$ & $754 \mathrm{~A}$ & $501 \mathrm{~B}$ & $218.85 \mathrm{~A}$ & $126.82 \mathrm{~B}$ \\
CV & & 3.29 & & & \multicolumn{3}{c}{4.96} &
\end{tabular}

${ }^{1}$ Means followed by the same lowercase letter in the column and uppercase letter in the row do not differ statistically from each other by the Scott-Knott test at 5\% probability; CV: Coefficient of variation (\%).

Remaining dry weight $\left(\mathrm{R}_{\mathrm{D}} \mathrm{WC}\right)$ was lower in the absence of stress, indicating greater use of pre-existing reserves in the cotyledons. Salt stress had a significant effect on this variable, with the stressed seeds using a smaller amount of reserves, leaving a larger amount in the cotyledons. Nonetheless, the seed lots of genotypes classified as high-vigor had a lower remaining dry weight, indicating greater use of the reserves as compared with the seed lots of cultivars BAF07 and BAF23, which showed the highest remaining dry weight in the cotyledons in both treatments (Table 3).

Final starch responded similarly to $\mathrm{R}_{\mathrm{D}} \mathrm{WC}$ in the salt stress situation. Stress resulted in decreased starch hydrolysis (Table 3). This happens because salinity influences the hydrolysis process and reserve mobilization during germination, thus delaying or inhibiting the seedling formation process depending on the intensity of stress (Ibrahim, 2016; Li, Zhao, Zhang, Yuan, \& Chen, 2019).
However, the highest starch reduction rates $\left(\mathrm{S}_{\mathrm{T}} \mathrm{RR}\right)$ were seen in genotypes BAF42, BAF55 and BAF81, and hydrolysis differed between the vigor groups in the absence of stress (Figure 1f).

Seed reserve reduction $\left(S_{D} R R\right)$, seed reserve reduction rate $\left(S_{D} R R R\right)$, seedling dry weight $\left(S_{L} D W\right)$ and reserve mobilization rate (RMR) differed significantly between cultivars, decreasing in the salt stress condition (Figure 1a, b, c and d). Cultivars BAF23, BAF55 and BAF112 showed the greatest reduction in reserves $\left(S_{D} R R\right)$ (Figure 1a), which favored the formation of seedlings with greater dry weight in the control condition (Figure 1c). Under salt stress, the reduction of reserves $\left(S_{D} R R\right)$ did not show the same response. Vigor showed to have an influence, with the heaviest seedling dry weight observed in cultivars BAF13, BAF55 and BAF112, which belong to the most vigorous group (Figure 1c). 


\section{Table 3}

Seed dry weight $\left(S_{D} D W\right)$, dry weight remaining in the cotyledons $\left(R_{D} W C\right)$ and amounts of starch before germination (Initial starch) and after five days of germination (Final starch) in the evaluated lots of seeds of common-bean cultivars in the absence (Control) and presence $(\mathrm{NaCl})$ of salt stress

\begin{tabular}{|c|c|c|c|c|c|}
\hline \multirow{2}{*}{ Cultivar } & \multirow{2}{*}{$\begin{array}{c}\mathrm{S}_{\mathrm{D}} \mathrm{DW} \\
\left(\mathrm{mg} \mathrm{seed}^{-1}\right)\end{array}$} & \multicolumn{2}{|c|}{$\mathrm{R}_{\mathrm{D}} \mathrm{WC}\left(\mathrm{mg} \mathrm{seed}^{-1}\right)$} & \multicolumn{2}{|c|}{$\mathrm{R}_{\mathrm{D}} \mathrm{WC}(\%)$} \\
\hline & & Control & $\mathrm{NaCl}$ & Control & $\mathrm{NaCl}$ \\
\hline BAF07 & $169.82 \pm 7.01$ & $113.14 \pm 6.89$ & $125.37 \pm 5.25$ & 68.40 a1 & $72.22 \mathrm{a}$ \\
\hline BAF13 & $183.91 \pm 1.15$ & $112.29 \pm 1.58$ & $133.14 \pm 11.81$ & $59.23 \mathrm{c}$ & $67.79 \mathrm{~b}$ \\
\hline BAF23 & $271.53 \pm 10.53$ & $179.78 \pm 10.19$ & $200.69 \pm 8.85$ & $66.88 \mathrm{a}$ & $74.27 \mathrm{a}$ \\
\hline BAF42 & $163.99 \pm 0.89$ & $91.96 \pm 0.49$ & $104.01 \pm 5.97$ & $56.74 \mathrm{c}$ & $62.61 \mathrm{c}$ \\
\hline BAF55 & $175.68 \pm 3.37$ & $91.20 \pm 1.66$ & $111.02 \pm 5.87$ & $50.86 d$ & $62.33 \mathrm{c}$ \\
\hline BAF81 & $174.63 \pm 4.84$ & $103.15 \pm 2.20$ & $120.67 \pm 5.46$ & $58.45 \mathrm{c}$ & $65.70 \mathrm{~b}$ \\
\hline BAF112 & $212.08 \pm 6.20$ & $130.88 \pm 3.73$ & $141.67 \pm 12.31$ & $62.35 b$ & $66.46 \mathrm{~b}$ \\
\hline Overall mean & $193.08 \pm 35.43$ & $117.48 \pm 30.39$ & $133.79 \pm 30.22$ & $60.41 \mathrm{~B}$ & $67.34 \mathrm{~A}$ \\
\hline CV & - & & & & \\
\hline \multirow{2}{*}{ Cultivar } & \multirow{2}{*}{$\begin{array}{l}\text { Initial starch } \\
\left(\mathrm{mg} \mathrm{seed}^{-1}\right)\end{array}$} & \multicolumn{2}{|c|}{ Final starch $\left(\mathrm{mg} \mathrm{seed}^{-1}\right)$} & \multicolumn{2}{|c|}{ Final starch (\%) } \\
\hline & & Control & $\mathrm{NaCl}$ & Control & $\mathrm{NaCl}$ \\
\hline BAF07 & $83.14 \pm 2.82$ & $41.26 \pm 1.98$ & $44.98 \pm 4.82$ & 49.72 a1 & $54.07 \mathrm{a}$ \\
\hline BAF13 & $95.92 \pm 13.81$ & $45.65 \pm 1.35$ & $63.51 \pm 10.60$ & $48.30 \mathrm{a}$ & $66.15 \mathrm{a}$ \\
\hline BAF23 & $132.86 \pm 26.16$ & $70.62 \pm 2.98$ & $83.27 \pm 11.73$ & $54.67 \mathrm{a}$ & $63.22 \mathrm{a}$ \\
\hline BAF42 & $85.14 \pm 13.02$ & $31.68 \pm 1.36$ & $47.39 \pm 3.33$ & $37.68 b$ & $56.45 a$ \\
\hline BAF55 & $86.10 \pm 11.24$ & $32.03 \pm 2.72$ & $42.51 \pm 6.56$ & $37.57 \mathrm{~b}$ & $49.60 \mathrm{a}$ \\
\hline BAF81 & $87.69 \pm 2.28$ & $37.66 \pm 1.87$ & $49.28 \pm 7.73$ & $42.95 b$ & $56.29 a$ \\
\hline BAF112 & $105.40 \pm 6.27$ & $56.32 \pm 1.11$ & $63.68 \pm 8.36$ & $53.59 a$ & $60.32 \mathrm{a}$ \\
\hline Overall mean & $96.61 \pm 19.67$ & $45.03 \pm 13.48$ & $56.37 \pm 15.42$ & $46.36 \mathrm{~B}$ & $58.01 \mathrm{~A}$ \\
\hline CV & - & \multicolumn{2}{|c|}{-} & \multicolumn{2}{|c|}{12.82} \\
\hline
\end{tabular}

${ }^{1}$ Mean \pm standard deviation; ${ }^{2}$ Means followed by the same lowercase letter in the column and uppercase letter in the row do not differ statistically from each other by the Scott-Knott test at 5\% probability; CV: Coefficient of variation (\%).

Seedling dry weight (S,DW) is the result of what was mobilized during the germination process. In general, S,DW increases with the reduction in the reserves present in the reserve tissue (X. Cheng et al., 2018). Thus, the cultivars in the high-vigor group (BAF13, BAF42, BAF55, BAF81 and BAF112) showed a greater capacity to reduce the cotyledon reserves ( $S_{D} R R R$ ) and mobilize them for seedling formation (RMR) (Figure $1 \mathrm{~b}$ and $1 \mathrm{c}$ ). Likewise, Andrade et al. (2019) evaluated the mobilization of reserves and vigor of maize seeds and observed that the seeds with greater vigor had greater capacity for depletion of reserves and greater mobilization for the seedlings.

The presence of salt stress during germination resulted in less use of stored seed reserves, affecting dry weight accumulation and seedling length. Baghel, Kataria and Jain (2019) observed this effect in maize seeds, which showed lower weight and length accumulation under salt stress conditions. 
The decrease in growth is caused by the occurrence of osmotic stress and, later, by ionic toxicity (i.e., absorption of $\mathrm{Na}^{+}, \mathrm{Cl}^{-}$), which results in intracellular imbalance, requiring osmotic adjustment (Taiz, Zeiger, Møller, \& Murphy, 2017; Liang et al., 2018). However, the seeds from the high-vigor group (Table 2; Figure 1d) showed better performance even in the presence of stress, demonstrating a greater capacity to germinate and form seedlings with greater length and dry weight under these conditions.
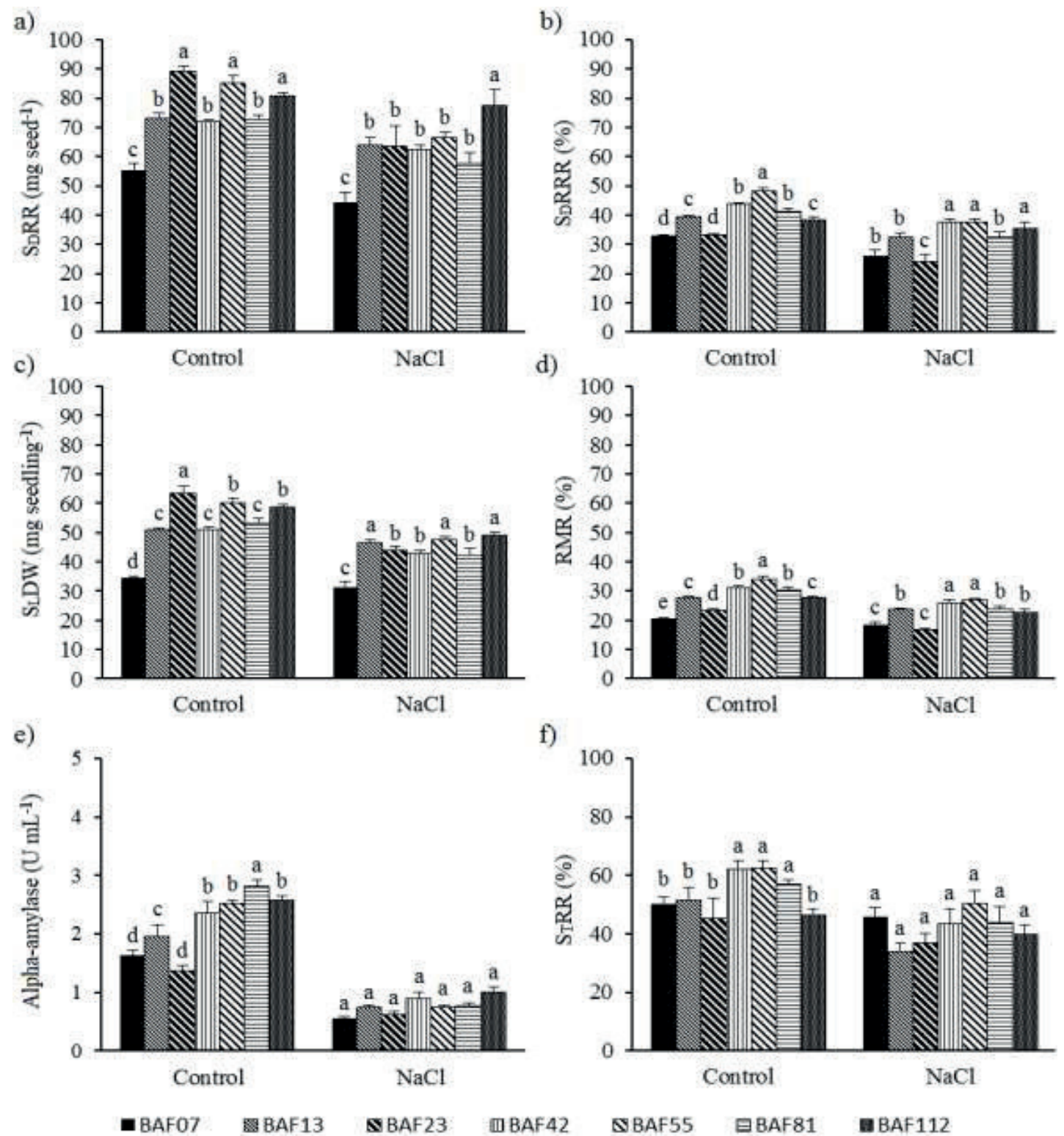

Figure 1. Seed reserve reduction $\left(S_{D} R R\right)$, seed reserve reduction rate $\left(S_{D} R R R\right)$, seedling dry weight $(S, D W)$, reserve mobilization rate (RMR), alpha-amylase enzyme activity and starch reduction rate ( $S_{T} R R$ ) in common bean cultivars evaluated under absence (Control) and presence of salt stress $(\mathrm{NaCl})$. Bars followed by the same lowercase letter within the treatment indicate no significant difference by the Scott-Knott test at $5 \%$ probability. 
In the absence of stress, cultivars BAF42, BAF55, BAF81 and BAF112 exhibited the highest alpha-amylase activity (Figure 1e). Among the seeds of the high-vigor group, genotype BAF13 had the lowest enzyme activity, but was superior to the low-vigor genotypes BAF07 and BAF23. This difference in activity within the high-vigor group may be associated with genotypic differences, considering that Oliveira et al. (2013) observed that maize lines of similar physiological quality may show differences in the expression of the alpha-amylase enzyme. The higher alphaamylase activity resulted in a higher starch reduction rate (Figure 1f) and a higher reserve reduction rate $\left(S_{D} R R R\right.$ ) (Figure $1 \mathrm{~b}$ ), with an association occurring between the high vigor of the cultivars and enzyme activity. After the cultivars were subjected to the salt stress condition, this relationship was no longer present, since there was a decrease in alphaamylase activity for all cultivars (Figure 1e). Nevertheless, starch reduction rate $\left(\mathrm{S}_{\mathrm{T}} \mathrm{RR}\right) \mathrm{did}$ not show a decrease in the same intensity, suggesting that, during stress, the enzyme alpha-amylase was less important during starch hydrolysis, since the seeds continued to exhibit starch depletion (Figure 1f).

Adda, Regagba, Latigui and Merah (2014) observed the impact of salt stress on alpha-amylase activity during the germination of common-bean seeds, describing that the reduction in activity increased as the stress was intensified, compromising seedling performance. The decline in alpha-amylase activity is due to the hormonal change that takes place in the seeds, which causes a decrease in the gibberellin content, ultimately inhibiting the utilization of reserves ( $\mathrm{Li}$ et al., 2019). The decreased alpha-amylase enzyme activity results in less starch hydrolysis, reducing the availability of soluble sugars for embryonic axis growth (Oliveira et al., 2013). This association between alpha-amylase enzyme activity, starch hydrolysis and sugar availability explains the lower seedling dry weight and lower reserve reduction observed in the presence of salt stress (Figure 1a, c).

Pearson correlation analysis revealed a significant positive correlation between alphaamylase activity and the vigor of the seed lot (Figure 2a). However, this association was not present when the seeds were subjected to salt stress, suggesting that vigor did not translate into greater alpha-amylase activity in the seeds at five days of germination (Figure 2b). L. T. Chen et al. (2017) identified this relationship, in which alpha-amylase activity and greater vigor in wheat seeds were not associated with each other under water stress conditions. Thus, it is possible that another mechanism influences hydrolysis capacity and the formation of seedlings with a heavier weight in this condition.

\section{Principal component analysis} (PCA) was performed to better understand the relationship between alpha-amylase activity and the vigor groups obtained and its association with seedling performance parameters. For the control condition, principal components 1 (PC1) and 2 (PC2) explained $59.82 \%$ and $26.83 \%$ of the data variability, respectively (Figure 3a). In PCA for stress conditions, PC1 and PC2 explained 53.73\% and $22.97 \%$ of the data variance, respectively (Figure 3b). The two vigor groups can be seen in PCA, which shows the association between the evaluated variables with each of the formed groups.

Principal component 1 allowed the separation of vigor groups regardless of the 
absence or presence of stress, and both PCA showed a similar association in relation to the variables. The $\mathrm{S}_{\mathrm{T}} \mathrm{RR}, \mathrm{RMR}, \mathrm{S}_{\mathrm{D}} \mathrm{RRR}, \mathrm{TL}, \mathrm{VI}$, $S_{L} D W, S_{D} R R$ and alpha-amylase variables were positively associated with each other and were associated with the high-vigor group (BAF13, BAF42, BAF55, BAF81 and BAF112). This result indicates that common-bean seeds with high vigor have greater alpha-amylase activity, which partially favors a greater reduction of reserves and a subsequent mobilization of the soluble compounds to the embryonic axis, promoting the formation of longer seedlings with a heavier dry weight (Figure 3).

The observed difference in association for alpha-amylase between Pearson's correlation (Figure 2b) and PCA (Figure 3b) may be related to the greater variability of this variable. According to Jolliffe and Cadima (2016), PCA reduces the dimensionality of the set by finding new variables that are linear functions of the original dataset, increasing interpretation capacity and reducing information loss.
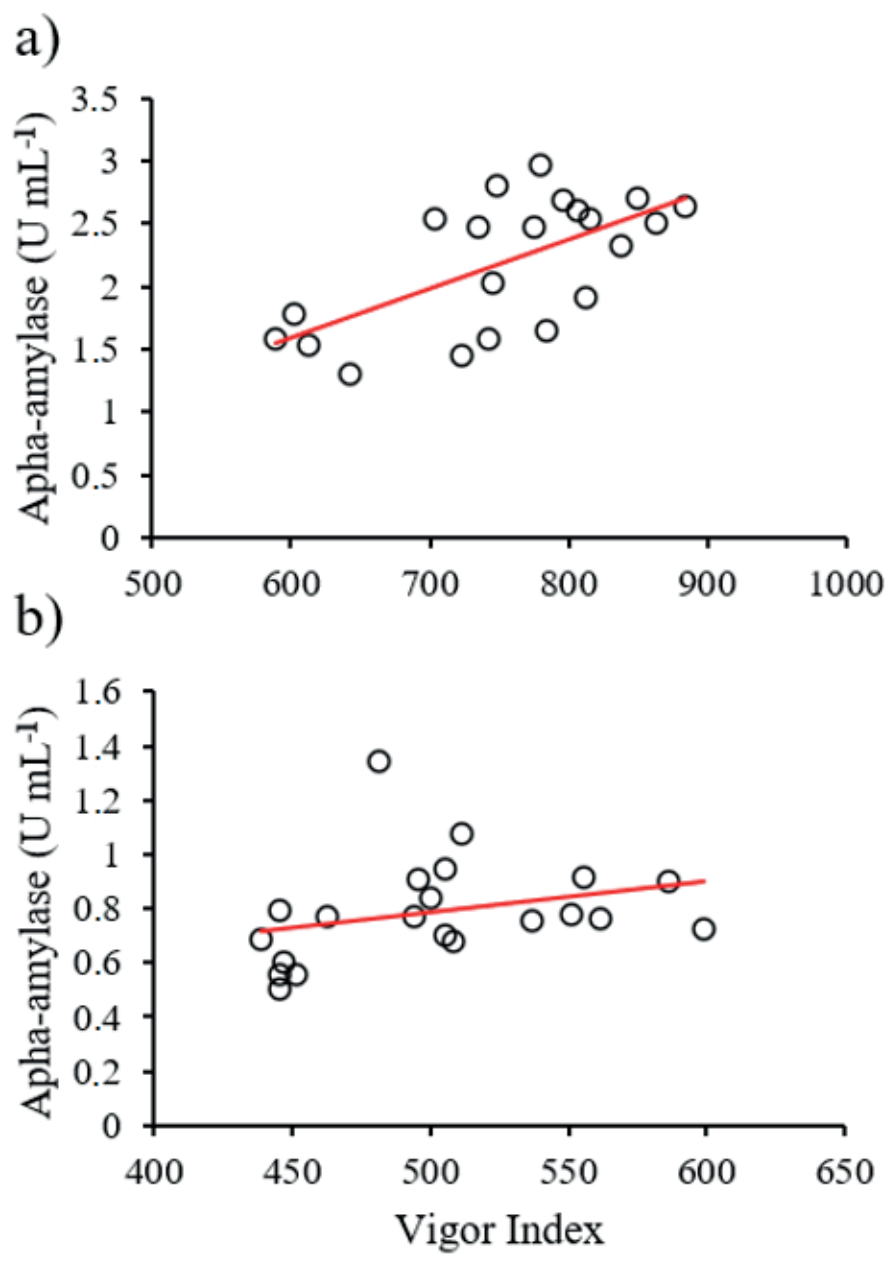

Figure 2. Pearson correlation analysis between vigor index and alpha-amylase activity obtained under optimal germination conditions $\left(r=0.64^{*}\right)(a)$ and under salt stress $\left(r=0.28^{\text {ns }}\right)$ (b). Significant at $1 \%\left(^{*}\right)$ and not significant (ns) by the t test. 
Results for alpha-amylase in the absence of stress (Figure 2a, Figure 3a) suggest its importance in the germination process of common-bean seeds, as it promotes better performance in seedlings from high-vigor seeds. However, other enzymes may be related to vigor, especially before the evaluated period. In maize seeds, the higher hydrolysis capacity is one of the main causes of rapid germination, with the formation of seedlings of higher performance (Naguib \& Abdalla, 2019). Similar results were also described in studies with rice seed (X. Cheng et al., 2013). On the other hand, RDWC was associated with the group of low-vigor seeds (BAF07 and BAF23), indicating less hydrolysis of reserves and, consequently, less mobilization (Figure 3a, b).

Unlike what was observed in the no-stress situation, the second principal component shows that, in the presence of salt stress (Figure $3 b$ ) starch reduction rate ( $\left.\mathrm{S}_{\mathrm{T}} \mathrm{RR}\right)(\mathrm{PC} 1+/ \mathrm{PC} 2-)$ and alpha-amylase activity (PC1+/PC2+) are not positively associated with each other. In general, alpha-amylase is the main enzyme responsible for starch hydrolysis in grasses (Yu et al., 2015). However, in dicots, starch hydrolysis can be performed by other enzymes; in chickpeas, for instance, the start of starch hydrolysis is a result of the activity of the enzyme starch phosphorylase, and during germination, the activity of amylases (i.e., alpha-amylase and beta-amylase) increases (Bewley et al., 2013). This difference may explain the previously observed results for alpha-amylase and starch reduction rate in the stress condition (Figure 1e, f). Considering the later increase in alpha-amylase activity during the germination of dicotyledonous seeds, the non-significant correlation between this enzyme and the vigor of the seed lot observed in the salt stress condition (Figure 2b), may be associated with the speed of the germination process, since salt stress resulted in seedlings of lower performance. It is hence suggested that a longer germination time is necessary to identify this relationship under stress conditions. 

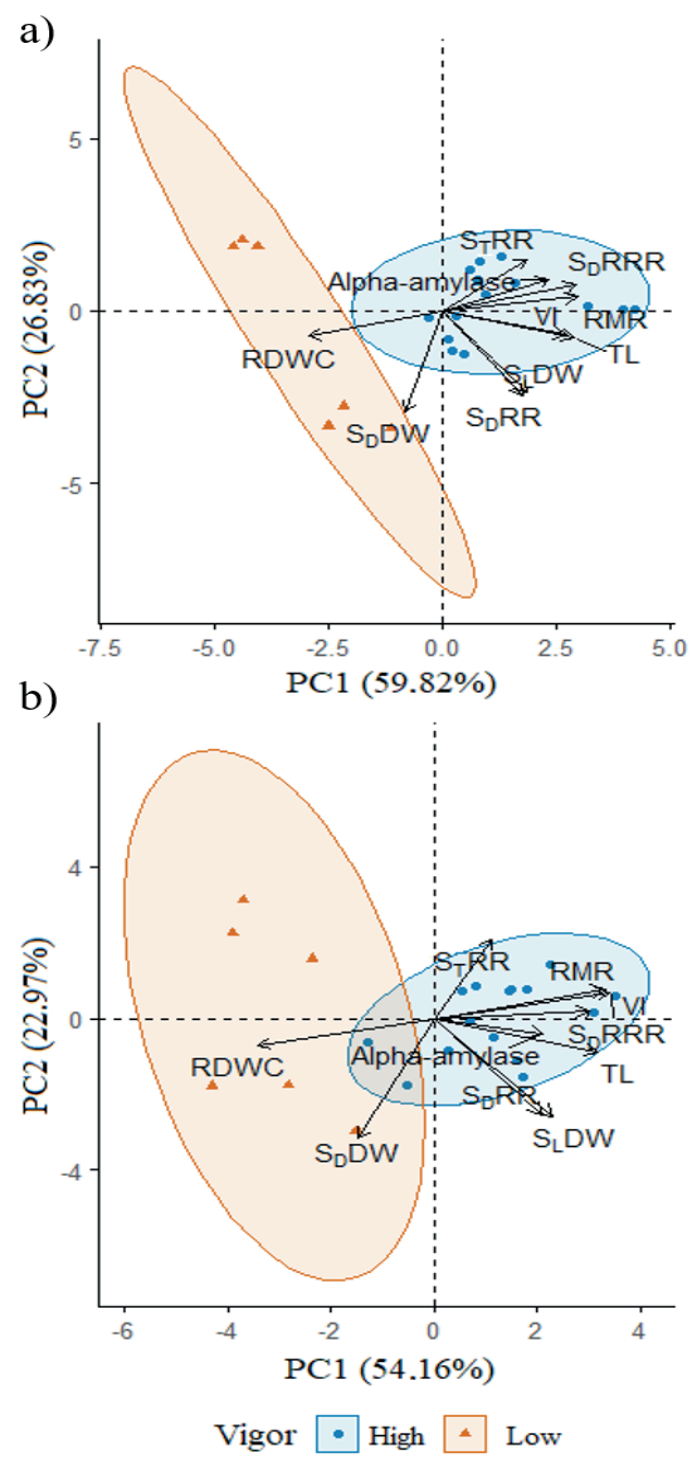

Figure 3. Principal component analysis regarding seedling formation in control (a) and under salt stress $\left(50 \mathrm{mmol} \mathrm{L}^{-1}\right)(\mathrm{b})$ and the association between the evaluated parameters. PC1 and PC2 are the first and second principal components, respectively.

Thus, under salt stress, when alphaamylase activity was affected (Figure 1e), it is possible that another catalyst molecule contributed to starch hydrolysis, which resulted in its depletion even during this stress, as highlighted above (Figure 1f). Similarly, according to Thalmann and Santelia (2017), the metabolic route related to starch hydrolysis can be altered in different environmental conditions, such as cold stress and water stress, changing the enzymes that hydrolyze starch. Therefore, it is recommended that other enzymes related to starch hydrolysis during the formation of common-bean seedlings be evaluated and identified in absence and presence of salt stress, as other enzymes associated with the vigor of seeds of that species may be indicated. 


\section{Conclusions}

The alpha-amylase enzyme activity is positively associated with the vigor of the seed lot under control conditions (i.e., absence of stress). However, when subjected to salt stress, the enzyme alpha-amylase does not show a direct association or has a weak association with vigor and starch hydrolysis. As such, it can't be indicated as the main factor related to starch hydrolysis and better performance of high-vigor seeds in salt stress conditions.

\section{Acknowledgments}

The first author thanks the Programa de Bolsas Universitárias de Santa Catarina UNIEDU and the Fundo de Apoio à Manutenção e ao Desenvolvimento da Educação Superior FUMDES for granting the doctoral scholarship. The authors would like to thank the financial support TR653PAP/UDESC/FAPESC. The corresponding author (Coelho, C.M.M) thanks Conselho Nacional de Desenvolvimento Científico eTecnológico (CNPq) for productivity scholarship. This article is part of Padilha, M. S Doctorate degree.

\section{References}

Adda, A., Regagba, Z., Latigui, A., \& Merah, O. (2014). Effect of salt stress on $\alpha$-amylase activity, sugars mobilization and osmotic potential of Phaseolus vulgaris $\mathrm{L}$. seeds var.'Cocorose'and'Djadida'duri ng germination. Journal of Biological Sciences, 14(5), 370-375. doi: 10.3923/ jbs.2014.370.375
Andrade, G. C. D., Coelho, C. M. M., \& Padilha, M. S. (2019). Seed reserves reduction rate and reserves mobilization to the seedling explain the vigour of maize seeds. Journal of Seed Science, 41(4), 488-497. doi: 10.1590/2317-1545v41n4227354

Baghel, L., Kataria, S., \& Jain, M. (2019). Mitigation of adverse effects of salt stress on germination, growth, photosynthetic efficiency and yield in maize (Zea mays L.) through magnetopriming. Acta Agrobotanica, 72(1), 1-16. doi: 10.5586/ aa. 1757

Bewley, J. D., Bradford, K. J., Hilhorst, H. \& Nonogaki, H. (2013). Seeds: physiology of development, germination and dormancy. New York: Springer Science \& Business Media.

Caverzan, A., Giacomin, R., Müller, M., Biazus, C., Lângaro, N. C., \& Chavarria, G. (2018). How does seed vigor affect soybean yield components?. Agronomy Journal, 110(4), 1318-1327. doi: 10.2134/agronj 2017.11.0670

Chen, J., Wu, J., Lu, Y., Cao, Y., Zeng, H., Zhang, Z.,... Wang, S. (2016). Molecular cloning and characterization of a gene encoding the proline transporter protein in common bean (Phaseolus vulgaris L.). The Crop Journal, 4(5), 384-390. doi: 10.1016/j. cj.2016.05.009

Chen, L. T., Sun, A. Q., Yang, M., Chen, L. L., Ma, X. L., Li, M. L., \& Yin, Y. P. (2017). Relationships of wheat seed vigor with enzyme activities and gene expression related to seed germination under stress conditions. Ying yong sheng tai xue bao: The Journal of Applied Ecology, 28(2), 609-619. doi: $10.13287 / j .1001-9332.201702 .019$ 
Cheng, J., Cheng, X., Wang, L., He, Y., An, C., Wang, Z., \& Zhang, H. (2015). Physiological characteristics of seed reserve utilization during the early seedling growth in rice. Brazilian Journal of Botany, 38(4), 751759. doi: 10.1007/s40415-015-0190-6

Cheng, X., Wu, Y., Guo, J., Du, B., Chen, R., Zhu, L., \& He, G. (2013). A rice lectin receptorlike kinase that is involved in innate immune responses also contributes to seed germination. The Plant Journal, 76(4), 687-698. doi: 10.1111/tpj.12328

Cheng, X., Xiong, F., Wang, C., Xie, H., He, S., Geng, G., \& Zhou, Y. (2018). Seed reserve utilization and hydrolytic enzyme activities in germinating seeds of sweet corn. Pakistan Journal of Botany, 50(1), 111-116.

Dutta, T., Neelapu, N. R. R., Wani, S. H., \& Challa, S. (2018). Response of pulses to drought and salinity stress response: a physiological perspective. In: S. H. Wani, \& M. Jain (Eds.), Pulse improvement (pp. 7798). Cham: Springer.

El-Mowafy, M. R., \& Kishk, A. M. S. (2017). Effect of soaking treatments and temperature during germination on germinability and rice (Oryza sativa L.) seed quality. Journal of Plant Production, 8(4), 537-540. doi: 10.21608/JPP.2017.40062

Gommers, C. M., \& Monte, E. (2018). Seedling establishment: a dimmer switch-regulated process between dark and light signaling. Plant Physiology, 176(2), 1061-1074. doi: 10.1104/pp.17.01460

Henning, F. A., Mertz, L. M., Jacob-Junior, E. A., Machado, R. D., Fiss, G., \& Zimmer, P. D. (2010). Composição química e mobilização de reservas em sementes de soja de alto e baixo vigor. Bragantia, 69(3), 727-733. doi: 10.1590/S0006-8705 2010000300026

Ibrahim, E. A. (2016). Seed priming to alleviate salinity stress in germinating seeds. Journal of Plant Physiology, 192(3), 3846. doi: 10.1016/j.jplph.2015.12.011

International Seed Testing Association (2014). Seed vigour testing. Zurich, Switzerland: International Rules for Seed Testing.

Jolliffe, I. T., \& Cadima, J. (2016). Principal component analysis: a review and recent developments. Philosophical Transactions of the Royal Society A: Mathematical, Physical and Engineering Sciences, 374(2065), 1-16. doi: 10.1098/ rsta.2015.0202

Kalai, T., Bouthour, D., Manai, J., Bettaieb Ben Kaab, L., \& Gouia, H. (2016). Salicylic acid alleviates the toxicity of cadmium on seedling growth, amylases and phosphatases activity in germinating barley seeds. Archives of Agronomy and Soil Science, 62(6), 892-904. doi: 10.1080/03650340.2015.1100295

Krzyzanowski, F. C., França-Neto, J. B., Gomes, F. G., Jr., \& Nakagawa, J. (2020). Testes de vigor baseados no desempenho das plântulas. In: F. C. Krzyzanowski, R. D. Vieira, J. B. França-Neto, J. Marcos-Filho, (Eds.), Vigor de sementes: conceitos e testes (pp. 79-140). Londrina, PR: ABRATES.

Li, J., Zhao, C., Zhang, M., Yuan, F., \& Chen, M. (2019). Exogenous melatonin improves seed germination in Limonium bicolor under salt stress. Plant Signaling \& Behavior, 14(11), 1659705. doi: 10.10 80/155 92324.2019.1659705 
Liang, W., Ma, X., Wan, P., \& Liu, L. (2018). Plant salt-tolerance mechanism: A review. Biochemical and Biophysical Research Communications, 495(1), 286-291. doi: 10.1016/j.bbrc.2017.11.043

Marcos-Filho, J. (2015). Seed vigor testing: an overview of the past, present and future perspective. Scientia Agricola, 72(4), 363374. doi: 10.1590/0103-9016-2015-0007

McCready, R. M., Guggolz, J., Silviera, V., \& Owens, H. S. (1950). Determination of starch and amylose in vegetables. Analytical Chemistry, 22(9), 1156-1158. doi: 10.1021/ac60045a016

Miller, G. L. (1959). Use of dinitrosalicylic acid reagent for determination of reducing sugar. Analytical Chemistry, 31(3), 426428. doi: 10.1021/ac60147a030

Ministério da Agricultura, Pecuária e Abastecimento. (2009). Regras para análise de sementes. Brasília: MAPA/ ACS. Recuperado de http://www. agricultura. gov.br/assuntos/laboratorios/ arquivospublicacoes-laboratorio/regrasparaanalise-de-sementes.pdf/view

Mondo, V. H. V., Nascente, A. S., \& Cardoso, M. O., Neto. (2016). Common bean seed vigor affecting crop grain yield. Journal of Seed Science, 38(4), 365-370. doi: 10.1590/2317-1545v38n4166814

Mukankusi, C., Raatz, B., Nkalubo, S., Berhanu, F., Binagwa, P., Kilango, M.,... Beebe, S. (2019). Genomics, genetics and breeding of common bean in Africa: a review of tropical legume project. Plant Breeding, 138(4), 401-414. doi: 10.1111/pbr.12573

Naguib, D. M., \& Abdalla, H. (2019). Metabolic status during germination of nano silica primed Zea mays seeds under salinity stress. Journal of Crop Science and Biotechnology, 22(5), 415-423. doi: 10.10 07/s 12892-019-0168-0

Oliveira, G. E., Pinho, R. G. V., Andrade, T. D., Pinho, É. V. D. R. V., Santos, C. D. D., \& Veiga, A. D. (2013). Physiological quality and amylase enzyme expression in maize seeds. Ciência e Agrotecnologia, 37(1), 40-48. doi: 10.1590/S1413-7054 2013000100005

R Core Team (2020). R: A language and environment for statistical computing. Austria: R Foundation for Statistical Computing.

Rocha, C. R. M. D., Silva, V. N., \& Cicero, S. M. (2015). Avaliação do vigor de sementes de girassol por meio de análise de imagens de plântulas. Ciência Rural, 45(6), 970-976. doi: 10.1590/0103-8478cr20 131455

Sako, Y., McDonald, M. B., Fujimura, K., Evans, A. F., \& Bennett, M. A. (2001). A system for automated seed vigour assessment. Seed Science and Technology, 29(3), 625636.

Silva, L. J. D., Medeiros, A. D. D., \& Oliveira, A. M. S. (2019). SeedCalc, a new automated $\mathrm{R}$ software tool for germination and seedling length data processing. Journal of Seed Science, 41(2), 250-257. doi: 10. 1590/2317-1545v42n2217267

Soltani, A., Gholipoor, M., \& Zeinali, E. (2006). Seed reserve utilization and seedling growth of wheat as affected by drought and salinity. Environmental and Experimental Botany, 55(1-2), 195-200. doi: 10.1016/j.envexpbot.2004.10.012 
Sun, Z., \& Henson, C. A. (1991). A quantitative assessment of the importance of barley seed $\alpha$-amylase, $\beta$-amylase, debranching enzyme, and $\alpha$-glucosidase in starch degradation. Archives of Biochemistry and Biophysics, 284(2), 298-305. doi: 10.1016/0003-9861(91)90299-X

Taiz, L., Zeiger, E., Møller, I. M., \& Murphy, A. (2017). Fisiologia e desenvolvimento vegetal. Porto Alegre: Artmed Editora.

Tayade, R., Kulkarni, K. P., Jo, H., Song, J. T., \& Lee, J. D. (2019). Insight into the prospects for the improvement of seed starch in legume: a review. Frontiers in Plant Science, 10, 1213. doi: 10.3389/fpls. 2019.01213
Thalmann, M., \& Santelia, D. (2017). Starch as a determinant of plant fitness under abiotic stress. New Phytologist, 214(3), 943-951. doi: 10.1111/nph.14491

Yu, S. M., Lo, S. F., \&Ho, T. H.D. (2015). Sourcesink communication: regulated by hormone, nutrient, and stress cross-signaling. Trends in Plant Science, 20(12), 844-857. doi: 10.1016/j.tplants.2015.10.009 
